\title{
Natural Fiber Thermal Insulation Materials from Fire Prevention Point of View
}

\author{
Linda Makovická Osvaldová $^{1, \star}$, Stanislava Gašpercová ${ }^{1}$ and Martin Petho ${ }^{2}$ \\ ${ }^{1}$ Univesity of Zilina, ul.1maja 32,Zilina 01026, Slovakia \\ ${ }^{2}$ Safirs, s.r.o., E.Bohuna 12, Ruzomberok 03401, Slovakia
}

\begin{abstract}
Natural fiber thermal insulation is rarely used in the Slovak republic. This low usage might be caused by various factors such as mistrust of new materials from the point of view of thermal insulation installation or of their behavior in case of fire. The paper focuses on the problem of their reaction to fire and behavior of these natural fiber materials in case of fire.
\end{abstract}

\section{Introduction}

Thermal insulation is a set of technical interventions enabling to build in additional thermal insulating layers usually on the outside.

Besides the thermal insulation protection and energy efficient proprieties, the additional thermal insulating system has to meet strict fire regulations specified by legal and normative regulations valid within the EU. It follows that - besides its structural proprieties - while choosing an insulation material we have to take into consideration its fire and technical proprieties.

\section{Thermal Insulation Materials}

The class of natural fiber thermal insulation includes nature-based building materials characterized by high thermal insulation properties. The category also comprises a variety of building materials such as industrial hemp, cork, wood-fiber boards, straw etc.

\subsection{Cork}

From the point of view of its proprieties, cork is a low combustible material with the degree of flammability of B2 ranking. Being so stiff and aging resistant, it is possible to use it for all varieties of building structures.

Besides its thermal insulation proprieties it has excellent sound performance therefore it is possible to use it as a thermal insulation as well as for soundproofing of the interior walls. Cork is easy to work with, it adheres to the base and can be plastered directly.

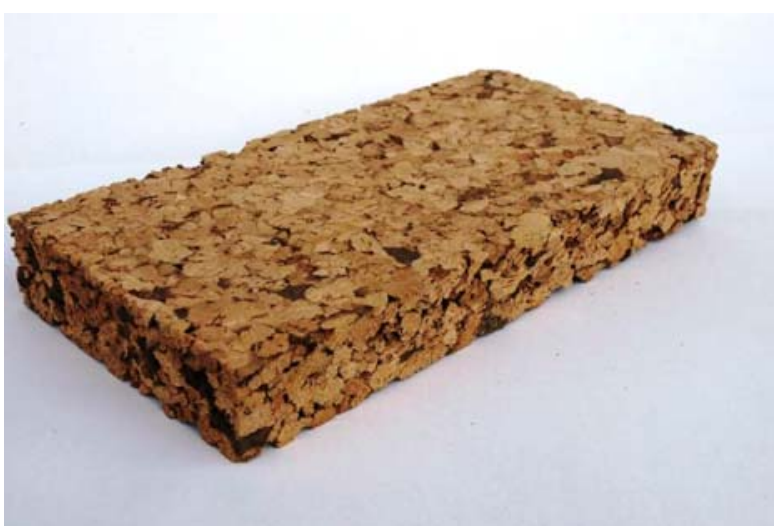

Figure 1. Cork

\subsection{Sheep's wool}

Sheep's wool is one of the most combustible materials belonging to the E category of degree of flammability. To increase its fire resistance it is treated with fire retardants. Since it doesn't lose its thermal insulation proprieties even at a humidity of $20 \%$, it works as an excellent thermal insulant against heat when applied from the outer part of the building structure. The wool is also mold and rot proof therefore it is suitable for constructions with a high humidity rate.

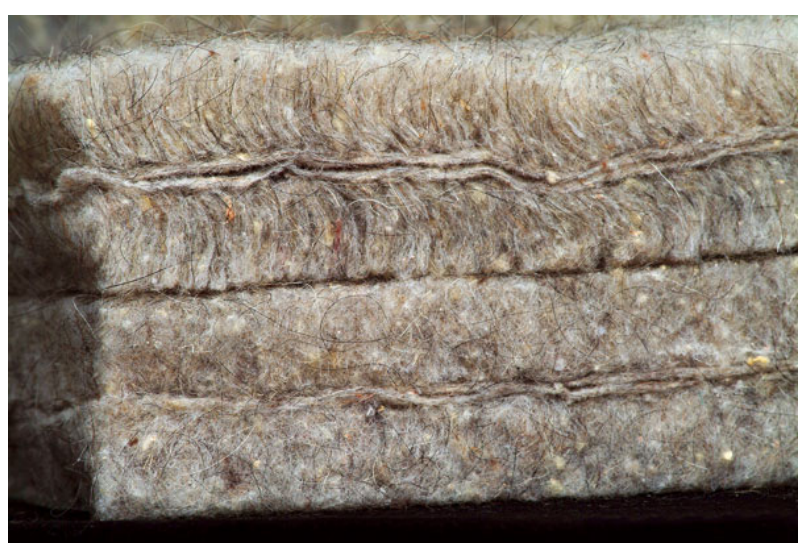

Figure 3. Sheep's wool 


\subsection{Wood-fiber boards}

Wood-fiber boards have a comparable thermal insulation proprieties as other insulation materials. They have a high thermal accumulation performance and a high volumetric mass density. Its advantages are of a great use especially in summer season as the boards are able to protect the interior against excessive overheating. Soundproof performance is sustained by pores in the wood. Relatively high price of the boards remains its biggest disadvantage. That's why they are often combined with other materials such as blown cellulose $[3,5]$.

Wood along with wood-fiber boards are materials which are flammable and burn well enough for the fire to spread onto the surrounding area. However, woodfiber boards can be shielded from fire by using admixtures which substantially influence its proprieties in case of a fire.

The most common is the admixture of ammonium phosphate. This substance helps the wood not to burn down to its core. The core remains solid, stable and intact while the wood is being combusted. Charred layers which protect the core have been created on the surface. It is proved that wood is the kind of material being able to withstand heat stress better than for example steel parts. Wood-fiber boards in combination with a suitable coating might ensure the fire resistance time as much as 60 minutes. What's more, wood, unlike other materials, doesn't release so many harmful substances into the air as other similar materials such as synthetic materials [4].

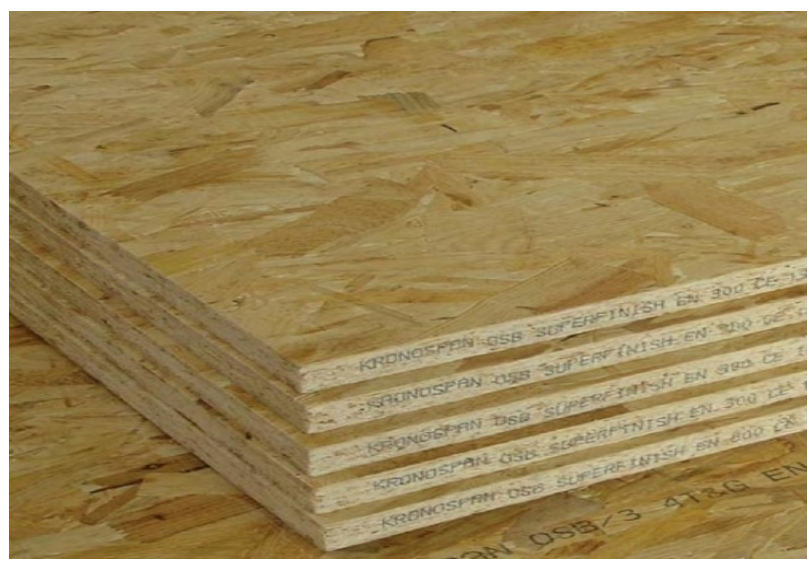

Figure 2. Wood-fiber boards

\section{Comparison of Basic Thermo- Technical And Fire-Technical Proprieties Of Insulation Materials}

When choosing insulation materials we should consider all criteria and proprieties of the materials which might influence the surroundings and the safety of the building construction [3]. The right choice of materials and systems for insulation is, among other things, influenced by the type of the building as well as the specific part we want to insulate. For example in case of a high-rise block of flats the insulation will not be carried out by thermo-insulating plasters.

Tab. 1: A comparison of proprieties of selected insulation materials

\begin{tabular}{|c|c|c|c|}
\hline Material & $\begin{array}{l}\text { Sheep's } \\
\text { wool }\end{array}$ & Cork & $\begin{array}{l}\text { Wood- } \\
\text { fiber } \\
\text { boards }\end{array}$ \\
\hline $\begin{array}{l}\text { Coefficient of } \\
\text { thermal } \\
\text { conductivity } \lambda\end{array}$ & 0,035 & 0,045 & $0,04-0,05$ \\
\hline $\begin{array}{c}\text { Security } \\
\text { measures during } \\
\text { insulation }\end{array}$ & no & no & gloves \\
\hline $\begin{array}{c}\text { Energy } \\
\text { consumption } \\
\text { for production }\end{array}$ & low & low & very low \\
\hline $\begin{array}{c}\text { Material } \\
\text { availability }\end{array}$ & $\begin{array}{l}\text { enough, is } \\
\text { renewable }\end{array}$ & $\begin{array}{l}\text { enough, is } \\
\text { renewable }\end{array}$ & $\begin{array}{l}\text { enough, is } \\
\text { renewable }\end{array}$ \\
\hline $\begin{array}{l}\text { Combustibility } \\
\text { degree } \\
\text { classification of } \\
\text { the material }\end{array}$ & $\mathrm{E}$ & B & $\mathrm{E}$ \\
\hline $\begin{array}{c}\text { Combustibility } \\
\text { degree } \\
\text { classification } \\
\text { within a } \\
\text { building } \\
\text { structure }\end{array}$ & $\mathrm{C}$ & B & B \\
\hline $\begin{array}{l}\text { Usage up to } \\
22,5 \mathrm{~m}\end{array}$ & yes & yes & Yes \\
\hline $\begin{array}{c}\text { Usage over } 22,5 \\
\mathrm{~m}\end{array}$ & no & no & No \\
\hline
\end{tabular}

It would require a technically complicated implementation as well as huge money investment. It is easier to use contact systems for perimeter segments in case of which hardened boards or bale wrapped materials are used. These are easier to manipulate with in the parts of buildings difficult to access or in case of irregular dimensions of some building constructions such as the ones in the attics or roof trussing. Along with the price margin while choosing an insulation material, sufficient fire safety should be also taken into consideration. Basic proprieties of the chosen insulation materials are stated in the table 1 .

\section{Conclusion}

In case of building fires it not possible to fully eliminate the risk of fire which might not only endanger the whole 
property but also the surrounding buildings. The insulations systems, if applied correctly and if the right insulation material has been chosen, can significantly reduce the risk of fire spreading onto other fire area or building. These are materials which don't contribute to fire spreading what is crucial for a potential evacuation of inhabitants and the arrival of the rescue services. On that account, when choosing an insulation material it is necessary to take into consideration both economical perspective of insulation as well as other factors including sufficient fire protection of the building construction to be insulated and the adjacent buildings.

\section{References}

[1] Lehocký, F. DVD board, [cit.: 2015-10-01]. Available on: http://blog.zdravydom.sk/drevovlaknite_dosk $\mathrm{y},(2012)$

[2] TEPORE s.r.o., DVD board and fire protection, [cit.: 2015-09-04]. Available on: http://tepore.sk/hlavne-vyhody/ochrana-protipoziaru/, (2013)

[3] Mitterová, I., Zachar, M. The comparison of flame retardants efficiency when exposed to heat. In: Modern thends in ergonomics and occupational safety. Zielona Góra : University of Zielona Góra, 207-226 (2013)

[4] Lingling Jiao, Guangdong Xu, Qingsong Wang, Qiang $\mathrm{Xu}$, Jinhua Sun, Kinetics and volatile products of thermal degradation of building insulation materials, Thermochimica Acta, 547, 120-125 (2012)

[5] Juráš, P., Korenková, R. Experimental Outdoor Measurements of the Wind-Driven Rain Influence on Various Coatings. In: Journal of Civil Engineering and Architecture Research. (2014) 